\title{
Technological indicators and productive performance of dairy cattle farming in the city of Rondon do Pará, state of Pará, Brazilian
} Amazon

\section{Indicadores tecnológicos e desempenho produtivo da pecuária leiteira bovina no município de Rondon do Pará, Amazônia Brasileira}

\author{
Bruno Cabral Soares ${ }^{1 *}$; Marcos Antônio Souza dos Santos ${ }^{2}$; Ana Laura dos \\ Santos Sena ${ }^{3}$; Antônio Cordeiro de Santana ${ }^{2}$; José Adérito Rodrigues Filho ${ }^{3}$; \\ Alfredo Kingo Oyama Homma ${ }^{3}$; André Guimarães Maciel e Silva ${ }^{4}$; \\ José de Brito Lourenço Júnior ${ }^{4}$
}

\begin{abstract}
The objective of this study was to evaluate the technological level and productive performance of the milk producing units of the municipality of Rondon do Pará in the state of Pará. Data were collected through interviews with questionnaires, conducted at 55 dairy farms, which accounted for $43.3 \%$ of the milked cows in the municipality. The factors that characterize the systems of bovine milk production were estimated by means of factorial analysis using 12 variables representative of the production units surveyed. Five factors were extracted: F1 = size of the enterprise; F2 = environment and nutrition; F3 $=$ technical assistance and herd management; F4 $=$ animal health; F5 $=$ schooling. From the scores associated with each factor, the index for productive performance of dairy cattle (DFPI) was calculated. The properties were classified into three levels of productive performance, including two considered to have a high level of DFPI, 16 with intermediate productive performance and 37 considered to have a low level of DFPI. There is a need to adopt technologies that promote the productive performance of dairy cattle in Rondon do Pará, as well as enable adaptation to socio-environmental public policies, with the aim of strengthening sustainable rural production through strategic actions that facilitate an increased technological level in farming systems production.
\end{abstract}

Key words: Dairy cattle farming. Productive performance. Eastern Amazon. Milk. Small producer.

\section{Resumo}

Avalia-se o nível tecnológico e o desempenho produtivo das unidades produtoras de leite do município de Rondon do Pará, estado do Pará. Os dados foram coletados a partir de entrevistas, com utilização de

1 Prof. Dr., Universidade Federal Rural da Amazônia, UFRA, Campus Paragominas, Paragominas, PA, Brasil. E-mail: brunocs@ veterinario.med.br

2 Profs. Drs., Instituto Socioambiental e dos Recursos Hídricos, ISARH/UFRA, Belém, PA, Brasil. E-mail: marcos.santos@ufra. edu.br; acsufra@gmail.com

3 Pesquisadores Drs., Empresa Brasileira de Pesquisa Agropecuária, EMBRAPA Amazônia Oriental, Belém, PA, Brasil. E-mail: ana-laura.sena@embrapa.br; aderito97@gmail.com; alfredo.homma@embrapa.br

4 Profs. Drs., Programa de Pós-Graduação em Ciência Animal, Instituto de Medicina Veterinária da Universidade Federal do Pará, IMV/UFPA, Castanhal, PA, Brasil. E-mail: andregms@gmail.com; joselourencojr@yahoo.com.br

* Author for correspondence 
questionários, realizadas em 55 propriedades leiteiras, que juntas representam 43,3\% do plantel de vacas ordenhadas do município. Os fatores que caracterizam os sistemas de produção de leite bovino foram estimados por meio de análise fatorial, utilizando 12 variáveis representativas das unidades de produção pesquisadas. Foram extraídos cinco fatores: $\mathrm{F}_{1}=$ tamanho do empreendimento; $\mathrm{F}_{2}=$ meio ambiente $\mathrm{e}$ nutrição; $\mathrm{F}_{3}=$ assistência técnica e manejo do rebanho; $\mathrm{F}_{4}=$ sanidade animal; e $\mathrm{F}_{5}=$ escolaridade. $\mathrm{A}$ partir dos escores associados a cada fator foi calculado o índice de desempenho produtivo da pecuária leiteira (IDPL). As propriedades foram classificadas em três níveis de desempenho produtivo, entre elas, duas consideradas com nível alto de IDPL, 16 com desempenho produtivo intermediário e 37 consideradas de nível baixo. Há necessidade da adoção de tecnologias para promover o desempenho produtivo da pecuária leiteira de Rondon do Pará, bem como possibilitar adequação às políticas públicas socioambientais, visando fortalecer a produção rural sustentável, por meio de ações estratégicas que viabilizem o aumento do nível tecnológico dos sistemas de produção.

Palavras-chave: Bovinocultura leiteira. Desempenho produtivo. Amazônia oriental. Leite. Pequeno produtor.

\section{Introduction}

Dairy activity in Brazil's North Region is undergoing intense structural modification, driven by changes in supply chain governance, market requirements, and an increase in the number of dairy enterprises implemented in areas where the informal market once prevailed. Consequently, regional production has grown by $5.5 \%$ over the past five years (IBGE, 2015).

The state of Pará accounts for $30 \%$ of the production in the North Region, behind only the state of Rondônia. Production grew from 566,777 thousand liters in 2010 to 567,231 thousand liters in 2015. The state's southeast mesoregion is the most representative, responsible for $71.34 \%$ of the total production. The city of Rondon do Pará, which is the target of this study, accounts for $2.4 \%$ of the state's total production (IBGE, 2015).

In the southeast mesoregion of Pará, dairy units (DU) carry out their activities using incipient technologies based on extensive use of natural resources and driven by a proximity to urban centers and dairy industries. The production system is inefficient due to limited technology adoption, lack of herd or facility specialization, poorly managed pastures leading to severe nutritional restriction, inadequate dietary supplementation, small production scale, and low productivity (SANTOS et al., 2014a; DANTAS et al., 2016a,b).
This requires instruments that enable the implementation of action in collaboration with the DUs, which leads to the development of productive performance. To that end, using methodologies that reflect the dynamics of complex and multidimensional systems by identifying and analyzing variables, indicators, and theirinteractions, in order to carefully assess their performance and sustainability should favor reaching the expected results (MARTINS et al., 2015). In the Amazon, studies using this methodological approach have already been developed for dairy cattle breeding in the states of Pará, Rondônia and Tocantins (SANTOS et al., 2014a,b).

Thus, this study aims to estimate a productive performance index of dairy farming (DFPI) to enable the adoption of technological innovations that promote gains in the productive performance and sustainable development of DUs in the city of Rondon do Pará, state of Pará, Brazil. The results should serve as a reference for sustainable rural development programs, among which is the Green Cities Program. This program was created to aid the municipalities' leaders in tackling deforestation in the Amazon and to strengthen sustainable development (COSTA; FLEURY, 2015), as well as to optimize land use and contribute to agriculture and livestock production that do not damage the environment. 


\section{Materials and Methods}

The study was developed in the city of Rondon do Pará (0446’45" S/48 04'00" W), southeast Pará mesoregion, state of Pará, Brazil, which has Ami climate with mean temperature of $26.35^{\circ} \mathrm{C}$, maximum temperature of $32.01{ }^{\circ} \mathrm{C}$, a minimum temperature of $22.71{ }^{\circ} \mathrm{C}$, and a mean relative humidity of $78 \%$, ranging from $100 \%$ to $52 \%$ in the rainier and less rainy seasons, respectively.

The data were collected from semi-structured questionnaire-based interviews carried out in 55 dairy properties that collectively represent $43.3 \%$ of the cattle herd milked in that municipality in 2014 (IBGE, 2015). The properties were selected using the snowball technique (BERNARD, 1988; ALEXIADES, 1996), with the help of technicians from the local office of the Technical Support and
Rural Extension Company (Empresa de Assistência Técnica e Extensão Rural - EMATER) of the state of Pará, the Municipal Secretary of Agriculture of Rondon do Pará, and the Association of Milk Producers (Associação de Produtores Amigos do Leite-AMILEITE) between 2012 and 2014.

The questions were grouped into the following categories: proprietor identification (12 questions), characterization of the production unit and dairy activity (21 questions), machines and equipment (21 questions), facilities and improvements (28 questions), herd health (16 questions), milking practices (28 questions), and herd management (10 questions). The technological variables considered important for the development of the productive performance were synthesized into 14 items and are listed in Table 1.

Table 1. Definition of the technological variables of dairy farming in the city of Rondon do Pará, state of Pará, during the period of 2012 to 2014 .

\begin{tabular}{lll}
\hline X1 & Infrastructure & Proportion of facilities, machines, and equipment that make up the dairy units. \\
X2 & Daily milk production & Number of liters produced per day at the dairy units. \\
X3 & Lactating cows & Lactating cows that make up the herd in the dairy units. \\
X4 & Number of cows in the herd & Cows that make up the herd in the dairy units. \\
X5 & Forage area & Total forage area of the dairy units (ha). \\
X6 & Nutritional management & Rate of supplementation and mineralization adopted by the dairy units. \\
X7 & Environment & Rate of adoption of measures to mitigate environmental impact. \\
X8 & Reproductive management & Proportion of dairy units that use natural mount and/or artificial insemination. \\
X9 & Milking management & Proportion of dairy units that use good milking practices. \\
& Technical support, training, & Proportion of dairy units that receive technical support and training and were \\
X10 & and credit & served by credit policies. \\
X11 & Sanitary management & Rate of technology adoption for sanitary control in the dairy units. \\
X12 & Schooling & Years of education of the dairy farmer. \\
\hline
\end{tabular}

After the variables were determined, the database underwent factorial analysis (FA), in order to identify the technological factors of dairy farming in Rondon do Pará. All data were stored in LibreOffice spreadsheets and then exported and analyzed in the GNU PSPP version 1.2.0 of the Free Software Foundation (FSF, 2018).

\section{Factorial analysis}

The original variables were examined by the FA used to analyze the structure of interrelations in a set of variables and identify the latent dimensions or factors, which may be expressed by linear combinations of correlated variables (MALHOTRA, 2004; HAIR JUNIOR et al., 2005; BEZERRA, 
2007; HÄRDLE; SIMAR, 2007). In order to verify the adequacy of the FA, Bartlett's test of sphericity and the Kaiser-Meyer-Olkin (KMO) test were employed (MINGOTI, 2005). The basic FA model can be expressed by the following:

$X_{i}=a_{i 1} F_{1}+a_{i 2} F_{2}+a_{i 3} F_{3}+a_{i 4} F_{4}+a_{i 5} F_{5}+U_{i}+E_{i}$

Where:

$$
i=1,2, \ldots, 55 \text { and } j=1,2, \ldots, 14 \text {; }
$$

$X_{i}=$ variables indicating the productive performance of the 55 DUs;

$F_{k}=\mathrm{k}^{\text {th }}$ common factor; $\mathrm{k}=1,2, \ldots, 5$

$a_{i k}=$ factorial loads that indicate the relations among the variables $X_{i}$ and the factors;

$U_{i}=$ unique factor that specifies the part of total variance that is not associated with the variance of other variables;

$E_{i}=$ term that represents the observation, measurement or specification error of the model.

The factorial scores for each of the DUs studied are estimated based on these factors. The overall expression to estimate the $\mathrm{j}^{\text {th }}$ factorial score $\left(F_{j}\right)$ is the following:

$F_{j}=w_{i 1} X_{1}+w_{i 2} X_{2}+w_{i 3} X_{3}+w_{i 4} X_{4}+w_{i 5} X_{5}+w_{i 4} X_{4}$

Where $w_{i j}$ represents the coefficients of the factorial scores and $p$ is the number of variables. An index was estimated based on those factorial scores to hierarchize the DUs in relation to the level of productive performance of dairy farming.

The properties were hierarchized based on the factorial scores, that is, the values of the factors for each of the 55 dairy farms. Thus, the dairy farming productive performance index (DFPI) was estimated by calculating the average of the factors weighed by the proportion of explanation for the total variance associated with each of them (SANTANA, 2007; SANTOS et al., 2014a,b). DFPI was calculated using the following expression:

$$
D F P I_{i}=\frac{\sum_{j=1}^{5} w_{j} \times P_{j}}{\sum_{j=1}^{5} w_{j}}
$$

Where:

$$
i=1,2, \ldots, 55 \text { and } j=1,2,3,4,5 \text {. }
$$

$D F P I_{i}=$ dairy farming productive performance index of the $i^{\text {th }}$ property;

$w_{j}=$ proportion of the variance explained by the $\mathrm{j}^{\text {th }}$ factor;

$\boldsymbol{P}_{i j}=$ value of the $\mathrm{j}^{\text {th }}$ standardized factorial score associated with the $\mathrm{i}^{\text {th }}$ property.

The factorial score was standardized, with the aim of obtaining positive values from the original score and allowing the properties to be hierarchized, since the DFPI must range from 0 to 100 . The following expression was used:

$$
P_{i j}=\left(\frac{F_{j}-F_{j}^{\min }}{F_{j}^{\max }-F_{j}^{\min }}\right) \times 100
$$

where

$F_{i j}^{\min }=$ lowest value of the $\mathrm{j}^{\text {th }}$ factorial score observed among all DUs;

$F_{i j}^{\max }=$ highest value of the $\mathrm{j}^{\text {th }}$ factorial score observed among all DUs.

The DFPI ranged from 0 to 100 and the following criteria were established: DFPI $\geq 80=$ High; $50<$ DFPI $<80=$ Intermediate; DFPI $\leq 50=$ Low. This reveals the direct relation between the DFPI value and the productive performance level and indicates that the closer the DU is to 100 , the better the productive performance of the city's dairy farming, which can serve as a model for the development of the activity (SANTOS et al., 2014a). 


\section{Results and Discussion}

Applying the factorial application enabled the extraction of five factors with characteristic roots above 1 that explained $75.38 \%$ of the data variance. Bartlett's test was significant at the $1 \%$ probability level, rejecting the null hypothesis that the correlation matrix is an identity matrix. The KMO test yielded a value of 0.612 , which indicates the data sample is adequate for the application of the FA (Table 2).

Table 2. Factorial loads after orthogonal rotation and similarities of the estimated factorial model for dairy cattle raising in Rondon do Pará, Northern Region of Brazil, 2012-2014.

\begin{tabular}{ccccccc}
\hline \multirow{2}{*}{ Variable } & \multicolumn{5}{c}{ Common factor } & \multirow{2}{*}{ Commonality* } \\
\cline { 2 - 5 } & $\mathrm{F} 1$ & $\mathrm{~F} 2$ & $\mathrm{~F} 3$ & $\mathrm{~F} 4$ & $\mathrm{~F} 5$ & 0.632 \\
X1 & 0.690 & 0.286 & 0.110 & -0.191 & 0.156 & 0.847 \\
X2 & 0.888 & -0.006 & 0.113 & 0.221 & -0.114 & 0.775 \\
X3 & 0.846 & -0.213 & 0.082 & 0.222 & -0.105 & 0.694 \\
X4 & 0.726 & -0.222 & -0.139 & -0.309 & -0.065 & 0.820 \\
X5 & 0.824 & 0.169 & -0.086 & 0.135 & 0.026 & 0.863 \\
X6 & 0.061 & 0.842 & 0.002 & -0.341 & 0.135 & 0.828 \\
X7 & -0.056 & 0.828 & 0.038 & 0.330 & -0.024 & 0.696 \\
X8 & 0.181 & 0.234 & 0.636 & 0.341 & 0.293 & 0.846 \\
X9 & -0.051 & 0.002 & 0.832 & -0.133 & -0.327 & 0.734 \\
X10 & -0.006 & -0.065 & 0.637 & 0.130 & 0.291 & 0.512 \\
X11 & 0.106 & -0.013 & 0.102 & 0.868 & 0.014 & 0.799 \\
X12 & -0.085 & 0.077 & 0.082 & -0.005 & 0.909 & 75.38 \\
\hline Variance explained (\%) & 20.07 & 13.87 & 13.17 & 11.48 & 9.81 & \\
\hline
\end{tabular}

Source: Research data. Note: Bartlett's test of sphericity $=258.643(\mathrm{p}<0.01)$ and KMO $=0.612$. $(*)$ Proportion of the total variance of the variable explained by the common factors. The factors with the greatest weight per variable are in bold.

Factor 1 explains the greatest share of the common variance in the data $(20.07 \%)$ and is positively associated with the variables $\mathrm{X}_{1}, \mathrm{X}_{2}$, $\mathrm{X}_{3}, \mathrm{X}_{4}$, and $\mathrm{X}_{5}$, which involve infrastructure, amount of milk produced per day, lactating cows, total cows in the herd, and forage area in the dairy properties of Rondon do Pará. The combination of those variables defined the overall characteristics of the DUs supporting the development of the activity. Therefore, the factor is called "Enterprise size." The variables "forage area" and "amount of milk produced per day" stand out, which drives the properties toward intensifying production in previously deforested areas, in order to contribute to native forest preservation, fertilizer use, and proper pasture management to reduce the need to expand production areas.

The second factor explains $13.87 \%$ of the variance and is positively related with variables $\mathrm{X}_{6}$ and $\mathrm{X}_{7}$, which represent the nutritional management and adoption of practices to mitigate environmental impact of dairy farming in Rondon do Pará, respectively. This factor was called "Environment and nutrition." It shows a strong positive correlation between the variables, with changes in feed management possibly leading to gains 
in the productive performance of dairy activity, such as proper sites for water supply, use of agroindustrial byproducts, intensification of pasture areas, adoption of technologies, such as integrated crop-livestock production that directly impacts animal well-being along with pasture tree coverage, among other measures that strengthen institutional and public policy actions (DANTAS et al., 2016b; SANTOS et al., 2014b).

The third factor explained $13.17 \%$ of the data variance and was defined by indicators $\mathrm{X}_{8}, \mathrm{X}_{9}$, and $\mathrm{X}_{10}$, which represent the adoption of reproductive management technologies, milking practice, access to credit, training, and technical support, a dimension called "Technical support and herd management." The association of those indicators is justified, as they represent technologies that directly impact the productivity of the DUs and are jointly applied in dairy systems. This factor stands out particularly in regard to credit availability, training, and technical support, variables that show the importance of the systemic view of dairy farming and greatly influences other variables. This highlights the significance of rural credit programs and technical support for the productive performance and modernization of the activity (SANTOS et al., 2013; SILVA et al., 2017). In Rondon do Pará, only a small portion of producers benefits from those services.

The fourth factor was called "Animal health." The highlight of this factor is indicator $\mathrm{X}_{11}$, which deals with the sanitary management of dairy farms, particularly due to repercussions from actions toward agriculture and livestock defense in the state, started in 2002 with the creation of the Agriculture and Livestock Defense Agency of the
State of Pará (Agência de Defesa Agropecuária do Estado do Pará-ADEPARÁ), with priority actions to eradicate foot-and-mouth disease. Such actions made much of the state territory that was free of footand-mouth disease through vaccination in 2007 and had a motivating effect on the adoption of measures for prophylaxis control of several pathologies that could affect the herd (PARÁ, 2016; MAPA, 2016).

The fifth factor, called "Schooling," which represents the producer's level of schooling, explained $9.81 \%$ of the data variance and has a single variable $\left(\mathrm{X}_{12}\right)$. The highlight is that most producers have only elementary school education, and this profile may negatively impact the adoption of technologies, such as good milking practices, that might enhance the productive performance of dairy farming in Rondon do Pará (DANTAS et al., 2016a; SOARES et al., 2013).

Based on the scores associated with each factor $\left(\mathrm{F}_{1}=\right.$ Enterprise size, $\mathrm{F}_{2}=$ Technical support and herd management, $\mathrm{F}_{3}=$ Environment and nutrition, $\mathrm{F}_{4}=$ Animal health, and $\mathrm{F}_{5}=$ Schooling), the DFPI could be estimated.

The overall mean DFPI was $39.09 \%$, which shows that most DUs have a low productive performance level, since this index ranges from 0 to 100 . By ordering the DFPI values, only two properties were considered to have a high performance level, whereas 16 had an intermediate level and 37 showed low productive performance. Table 3 shows the rate of technology adoption in the dairy farms of Rondon do Pará, based on the 55 properties studied and the averages of technological and productive performance variables grouped into three levels. 
Table 3. Rate of technology adoption in the dairy farms of Rondon do Pará and technological and productive performance variables grouped into three levels of the dairy farming productive performance index (DFPI) for the period of 2012 to 2014.

\begin{tabular}{cccccc}
\hline \multirow{2}{*}{ Technology } & \multicolumn{3}{c}{ Productive performance level (\%) } & \multirow{2}{*}{ Overall average } & \multirow{2}{*}{ F-test } \\
\cline { 2 - 4 } & High & Intermediate & Low & & 32.20 \\
\hline Infrastructure & 60.53 & 35.20 & 29.37 & $15.02^{*}$ \\
Feed management & 48.49 & 51.52 & 43.73 & 46.17 & $2.42^{\text {ns }}$ \\
Sanitary management & 85.72 & 86.61 & 74.13 & 78.18 & $3.90^{*}$ \\
Reproductive management & 62.50 & 51.56 & 16.89 & 28.64 & $17.51^{*}$ \\
Milking management & 45.84 & 51.04 & 46.73 & 47.95 & $0.88^{\text {ns }}$ \\
Technical support & 100.00 & 47.92 & 38.74 & 43.64 & $4.10^{*}$ \\
Environment & 60.00 & 53.13 & 4.00 & 44.55 & $4.05^{*}$ \\
Schooling & 2.50 & 2.06 & 1.54 & 1.73 & $0.89^{\text {ns }}$ \\
Forage area (ha) & 657.50 & 323.49 & 125.77 & 202.63 & $18.44^{*}$ \\
Amount of milk & 470.00 & 248.32 & 135.21 & 180.29 & $16.91^{*}$ \\
Lactating cows & 80.00 & 57.25 & 31.14 & 40.51 & $9.22^{*}$ \\
Number of cows & 145.00 & 100.75 & 87.27 & 93.29 & $0.68^{\text {ns }}$ \\
Productivity (L/cow/day) & 5.90 & 4.59 & 4.34 & 4.47 & $2.05^{*}$ \\
\hline
\end{tabular}

${ }^{*} \mathrm{p}<5 \%$. ${ }^{\text {ns }}$ Non-significant

The two properties with a high (DFPI $\geq 80$ ) productive performance level have superior infrastructure characteristics than the other levels, particularly facilities, such as a milking room and handling corral, and equipment, such as a mechanical milking machine and cooling tank, similar to that reported by Dantas et al. $(2016 a, b)$ in research on the same region of the municipality targeted by this study.

Feeding technologies and forage areas are used incipiently, regardless of the DFPI of the dairy farms in Rondon do Pará. Fertilization technologies for pasture recovery are not employed, which leads to a need for broad degraded areas or areas under a degradation process (DIAS-FILHO, 2011). As for feeding, despite differences caused by the time of year, most producers keep animals exclusively in pastures and only 34\% complement diet with concentrated supplements or roughage, sugar cane or agro-industry byproducts, usually in the summer, while most producers provide mineral lick mixed with white salt at a 1:1 ratio. Such technologies do not statistically differ in relation to the low productive performance level and may negatively impact herd health by causing, for example, slow development, fertility issues, low carcass yield, and low milk productivity, which harm the economic performance of the system (TOKARNIA et al., 2000).

The health variable is most regularly adopted among the studied properties, likely due to the implementation of public policies for the control and eradication of diseases, such as foot-andmouth disease, brucellosis, and tuberculosis, by the governmental programs managed by ADEPARÁ (SANTOS et al., 2014a), which is routine in the sanitary management of the properties. Nevertheless, some practices, such as deworming and drying up the umbilical stump, are used incipiently on the farms.

When the breeding variable is analyzed, the properties classified as having intermediate $(51.56 \%)$ and high $(62,50 \%)$ productive performance have the best numbers, which shows the importance of husbandry management for dairy farming, since the 
adoption of technologies like artificial insemination promotes significant genetic gains in the herd and increases productivity (LOURENÇO JUNIOR; SANTOS, 2015). However, only eight properties employ this practice.

Milking practice adoption did not differ $(\mathrm{p}<5 \%)$ among the levels. Technologies, such as a milking parlor, mechanized milking, milking management, and cleaning udders, recipients and facilities are adopted incipiently in the production units of Rondon do Pará and directly impact compliance with Normative Instruction 62 of the Ministry of Agriculture, Livestock, and Food Supply (MAPA) (BRASIL, 2011).

Technical support is a great differential for dairy farming in the city. The farms where productive performance is considered high (DFPI $\geq 80$ ) are assisted by some technicians. However, only two producers have specialized follow-ups, besides attending training courses that bring them closer to new technologies and having access to credit, a major instrument for guiding investments and technology toward the activity (LOURENÇO JUNIOR; SANTOS, 2015).

A statistical difference was found for the environment variable among the DFPI levels ( $p$ $<5 \%$ ). This variable is based on the adoption of mitigating measures, such as maintaining vegetation for water sources, intensifying the use of deforested areas, not using slash-and-burn, and knowing the Brazilian Forest Code. However, the use of such measures is still lacking for an efficient dairy farming practice, which, in the short term, should transition toward more sustainable technological alternatives (MARTINS et al., 2015).

Schooling, irrespective of the productive performance level, is low. Most producers (56.36\%) have incomplete elementary school education, while $9 \%$ are illiterate. Borsanelli et al. (2014) report difficulties for milk producers with only an elementary school education in adopting good milking practices. This hampers the technological innovation process for dairy farming in Rondon do Pará.

Nevertheless, the research data indicate two properties with a high productive performance level (DFPI $\geq 80$ ) that, besides having differentiated characteristics for the adoption of infrastructure technology $(60.53 \%)$, reproductive management $(62.50 \%)$, and receiving technical support (100\%), show important advances toward environment preservation $(60 \%)$ and better numbers regarding forage areas, milk production, cows in lactation, and productivity (L/cow/day) (Table 2). Such units may serve as a reference for enabling the expansion of the productive performance of dairy farming in the city and drive producers toward sustainability principles, as predicted in green-city policies.

No statistical difference was found in the number of cows in the herd $(p<5 \%)$. However, the percentage of cows in lactation significantly differs, despite the results indicating that properties classified with a high productive performance level (DFPI $\geq 80$ ) have better figures for this variable $(80.00 \%)$, close to the recommended level of $83 \%$ (MARTINS et al., 2015). The productivity (L/cows/ day) of the herds studied is not desirable for dairy farms with satisfactory productive performance, although the statistical difference $(\mathrm{p}<5 \%)$ among the DFPI levels in Rondon do Pará shows that the properties with a high DFPI exhibit the best numbers for this variable (5.9 L/cow/day) and stand out regarding the level of technology adoption in the city. This may indicate a path for the sustainable development of dairy farming in Rondon do Pará, seeking to achieve higher levels of productivity and compatible with that obtained in Rondônia, which is the state in the Northern Region of Brazil with the highest technological level in dairy farming (SANTOS et al., 2011).

The results based on the DFPI in Rondon do Pará may lay the basis for green-city public policies and facilitate the reaching of the goals set by the program, fight off deforestation, 
leverage productive performance, and promote sustainable rural production. They will also benefit a simplification of the environmental regularization process of rural properties, enable access to rural credit, suspension of fines applied by environmental organs and conversion into environmental recovery services, time for recovering environmental damage in permanent preservation and legal reserve areas of the property, governmental support with technical support and extension programs, environmental training and education, along with other actions that may optimize land use and contribute to sustainable local development (COSTA; FLEURY, 2015).

\section{Conclusions}

Splitting the properties into three levels indicated that only two farms have high productive performance, while 16 have intermediate and 37 have low performance.

This shows the deficiencies that limit the productive performance of dairy cattle in Rondon do Pará. Because the activity is developed without technical support and the support of training programs, the facilities are precariously placed, and the milking hygiene practices are incipient. Access to credit is limited and, thus, producers find it difficult to produce sustainably and comply with environmental legislation.

There is a need for investment in infrastructure, technical assistance, and training to adopt technologies that increase the productive performance of the activity. Additionally, access to policies should be made feasible to strengthen and intensify sustainable rural production through strategic actions involving socioeconomic and environmental dimensions.

\section{Acknowledgements}

The authors are thankful to Embrapa Eastern Amazon for help with data collection and assessment through the PISA II Project, to the Pará Amazon Foundation - Fapespa for funding the project "Assessment of Milk Quality and Production of Derivates in Family Agriculture of the Northeast and Southeast Pará Mesoregions" - QUALILEITE through notice 006/2010 and to CAPES for the doctorate scholarship.

\section{References}

ALEXIADES, M. N. Collecting ethnobotanical data: an introduction to basic concepts and techniques. In: ALEXIADES, M. N. (Org.). Selected guidelines for ethnobotanical research: a field manual. New York: NYBG, 1996. p. 53-94.

BERNARD, H. R. Research methods in cultural anthropology. Newbury Park: Sage Publications, 1988. $519 \mathrm{p}$.

BEZERRA, F. A. Análise fatorial. In: CORRAR, L. J.; PAULO, E.; DIAS FILHO, J. M. (Coord.). Análise multivariada: para os cursos de administração, ciências contábeis e economia. São Paulo: Ed. Atlas, 2007. p. 73130.

BORSANELLI, A. C.; SAMARA, S. I.; FERRAUDO, A. S.; DUTRA, I. S. Escolaridade e volume de produção têm associação com a percepção de risco de produtores de leite no uso de produtos veterinários. Pesquisa Veterinária Brasileira, Rio de Janeiro, v. 34, n. 10, p. 981989, 2014. DOI: 10.1590/S0100-736X2014001000010.

BRASIL. Ministério da Agricultura, Pecuária e Abastecimento. Instrução Normativa $n^{\circ} 62$ de 29 dezembro de 2011. Aprova o Regulamento Técnico de Produção, Identidade e Qualidade do Leite tipo A, o Regulamento Técnico de Identidade e Qualidade de Leite Cru Refrigerado, o Regulamento Técnico de Identidade e Qualidade de Leite Pasteurizado e o Regulamento Técnico da Coleta de Leite Cru Refrigerado e seu Transporte a Granel, em conformidade com os Anexos desta Instrução Normativa. Diário Oficial [da] República Federativa do Brasil, Brasília, 31 dez. 2011. Seção 1, p.6-11.

COSTA, J. M.; FLEURY, M. F. O. Programa Municípios Verdes: estratégias de revalorização do espaço em municípios paraenses. Ambiente \& Sociedade, Campinas, v. 18 , n. 2, p. 59-74, 2015. DOI: 10.1590/1809-4422ASOCEx04V1822015en

DANTAS, V. V.; OAIGEN, R. P.; SANTOS, M. A. S.; GODOY,B.S; SILVA, F.; CORREAA, R.P.; DOMINGUES, F. N.; MARQUES, C. S. S. Characteristics of cattle breeders and dairy production in the southeastern and 
northeastern mesoregions of Pará state, Brazil. Semina: Ciências Agrárias, Londrina, v. 37, n. 3, p. 1475-1488, 2016a. DOI: 10.5433/1679-0359.2018v39n5p2113

DANTAS, V. V.; OAIGEN, R. P.; SANTOS, M. A. S.; MARQUES, C. S. S.; SILVA, F. Typology of dairy production systems in the Eastern Amazon, Pará, Brasil. Livestock Research for Rural Development, Cali, v. 28, n. 6 , p. 1-10, 2016b. DOI: 10.5433/1679-0359.2018v39 n5p2113.

DIAS-FILHO, M. B. Desafios da produção animal em pastagens na fronteira agrícola brasileira. Belém: Ed. Embrapa Amazônia Oriental, 2012. 34.

FREE SOFTWARE FOUNDATION - FSF. Gnu PSPP. Boston: FSF, 2018. Available at: https://www. gnu.org/ software/pspp/. Accessed at: 17 fev. 2018.

HAIR JUNIOR, J. F.; BABIN, J. B.; ANDERSON, R. E.; TATHAM, R. L.; BLACK, W. C. Multivariate data analysis. $6^{\text {th }}$ ed. Upper Saddle River: Prentice Hall, 2005. $593 \mathrm{p}$.

HÄRDLE, W.; SIMAR, L. Applied multivariate statistical analysis. $2^{\text {th }}$ ed. Berlin: Springer, 2007. 160 p.

INSTITUTO BRASILEIRO DE GEOGRAFIA E ESTATÍSTICA - IBGE. Pesquisa pecuária municipal. Rio de Janeiro: Ed. IBGE, 2015. v. 43, p. 1-49.

LOURENÇO JUNIOR, J. B.; SANTOS, M. A. S. Qualileite: qualidade e tecnologia na cadeia produtiva do leite no estado do Pará. Belém: Ed. Marques Editora, 2015. 324 p.

MALHOTRA, N. Análisis factorial. Investigación de mercados. Cidade do México: Ed. Pearson Educación, 2004. 816 p.

MARTINS, P. C.; PICCININI, G. A.; KRUG, E. E. B.; MARTINS, C. E.; LOPES, F. C. F. Sustentabilidade ambiental, social e econômica da cadeia produtiva do leite: desafios e perspectivas. Brasília: EMBRAPA, 2015. 432 p.

MINGOTI, S. A. Análise de dados através de métodos de estatística multivariada: uma abordagem aplicada. Belo Horizonte: Ed. UFMG, 2005. 295 p.

MINISTÉRIO DA AGRICULTURA, PECUÁRIA E ABASTECIMENTO - MAPA. Evolução geográfica do processo de implantação de zona livre de febre aftosa no Brasil. Brasília: MAPA, 2016. Disponível em: http:// www.agricultura.gov.br/febreaftosa. Acesso em: 5 dez. 2016.

PARÁ. Lei $n^{\circ}$ 6.842, de 17 de setembro de 2002. Dispões sobre a criação da Agência de Defesa Agropecuária do Estado do Pará (ADEPARÁ) e dá outras providências.
Belém: ADEPARÁ, 2002. Disponível em: http://www. pge.pa.gov.br/sites/default/files/lo6482repub_alt.pdf. Acesso em: 5 dez. 2016.

SANTANA, A. C. Índice de desempenho competitivo das empresas de polpa de frutas do estado do Pará. Revista de Economia e Sociologia Rural, Brasília, v. 45, n. 3, p. 749775, 2007. DOI: 10.1590/S0103-20032007000300009

SANTOS, A. V. C; SANTOS, M. A. S.; REBELLO, F. K.; OLIVEIRA, C. M. The rural credit policy and the financing of the dairy cattle in the State of Pará in the period 1990-2010. Nucleus, Ituverava, v. 10, n. 2, p. 95101, 2013. DOI: 10.3738/1982.2278.925

SANTOS, M. A. S.; SANTANA, A. C.; RAIOL, L. C. B.; LOURENÇO JÚNIOR, J. B. Determining factors of modernization of dairy farming in the Brazilian Amazon. Livestock Research for Rural Development, Cali, v. 26, n. 10, p. 172-176, 2014b.

SANTOS, M. A. S.; SANTANA, A. C.; RAIOL, L. C. B. Índice de modernização da pecuária leiteira no estado de Rondônia: determinantes e hierarquização. Perspectiva Econômica, São Leopoldo, v. 7, n. 2, p. 93-106, 2011. DOI: $10.4013 /$ pe.2011.72.03

SANTOS, M. A. S.; SOARES, B. C.; DOMINGUES, F. N.; LOURENÇO JÚNIOR, J. B.; SANTANA, A. C. Avaliação do nível tecnológico da pecuária leiteira no estado do Pará. Amazônia: Ciência \& Desenvolvimento, Belém, v. 9, n. 18, p. 79-96, 2014a.

SANTOS, M. A. S.; SANTANA, A. C.; RAIOL, L. C. B.; LOURENÇO JÚNIOR, J. B. Fatores tecnológicos de modernização da pecuária leiteira no estado do Tocantins. Revista em Agronegócios e Meio Ambiente, Maringá, v. 7, n. 3, p. 591-612, 2014 b.

SILVA, J. M.; SANTOS, M. A. S.; REBELLO, F. K.; LOPES, M. L. B.; LOURENÇO JÚNIOR, J. B. Impacts of rural credit on the milk production in the State of Rondônia, 1990 - 2015. Nucleus Animalium, Ituverava, v. 9, n. 2, p. 81-90, 2017. DOI: 10.3738/21751463.2839

SOARES, S. O.; OAIGEN, R. P.; BARBOSA, J. D.; OLIVEIRA, C. M.C.;ALBERNAZ, T. T.; DOMINGUES, F. N.; MAIA, J. T. S.; CHRISTMANN, C. M. Perfil dos produtores de leite e caracterização técnica das propriedades leiteiras dos municípios de Rondon do Pará e Abel Figueiredo, Estado do Pará. Veterinária em Foco, Canoas, v. 10, n. 2, p. 159-168, 2013.

TOKARNIA, C. H.; DÖBEREINER, J.; PEIXOTO, P. V. Deficiências minerais em animais de fazenda, principalmente bovinos em regime de campo. Pesquisa Veterinária Brasileira, Rio de Janeiro, v. 20, n. 3, p. 127138, 2000. DOI: 10.1590/S0100-736X2000000300007 